\title{
Pathogenic potential of bacteria isolated from commercial biostimulants
}

\author{
Daniela Bulgari $^{1}$ [C Silvia Filisetti ${ }^{2} \cdot$ Matteo Montagna $^{3,4} \cdot$ Emanuela Gobbi $^{1} \cdot$ Franco Faoro $^{2}$
}

Received: 27 July 2021 / Revised: 13 January 2022 / Accepted: 17 January 2022 / Published online: 4 February 2022

(c) The Author(s) 2022

\begin{abstract}
Microbial-based products are a promising alternative to agrochemicals in sustainable agriculture. However, little is known about their impact on human health even if some of them, i.e., Bacillus and Paenibacillus species, have been increasingly implicated in different human diseases. In this study, 18 bacteria were isolated from 2 commercial biostimulants, and they were genotypically and phenotypically characterized to highlight specific virulence properties. Some isolated bacteria were identified as belonging to the genus Bacillus by BLAST and RDP analyses, a genus in-depth studied for plant growth-promoting ability. Moreover, 16S rRNA phylogenetic analysis showed that seven isolates grouped with Bacillus species while two and four clustered, respectively, with Neobacillus and Peribacillus. Unusually, bacterial strains belonging to Franconibacter and Stenotrophomonas were isolated from biostimulants. Although Bacillus species are generally considered nonpathogenic, most of the species have shown to swim, swarm, and produced biofilms, that can be related to bacterial virulence. The evaluation of toxins encoding genes revealed that five isolates had the potential ability to produce the enterotoxin $\mathrm{T}$. In conclusion, the pathogenic potential of microorganisms included in commercial products should be deeply verified, in our opinion. The approach proposed in this study could help in this crucial step.
\end{abstract}

Keywords Sustainable agriculture $\cdot$ Bacillus $\cdot$ Franconibacter $\cdot$ Swimming $\cdot$ Swarming

\section{Introduction}

Microbial products represent a promising alternative to agrochemicals in a sustainable agriculture either as biopesticides or biofertilizers or biostimulants (Bulgari and Faoro 2018;

Communicated by Erko Stackebrandt.

Daniela Bulgari

daniela.bulgari@unibs.it

1 Agri-Food and Environmental Microbiology Platform (PiMiAA), Department of Molecular and Translational Medicine, University of Brescia, viale Europa, 11, 25123 Brescia, Italy

2 Department of Agricultural and Environmental Sciences Production, Landscape, Agroenergy, University of Milan, via Celoria 2, 20133 Milan, Italy

3 BAT Center - Interuniversity Center for Studies On Bioinspired Agro-Environmental Technology, University of Napoli "Federico II", Portici, Italy

4 Department of Agricultural Sciences, University of Naples "Federico II", Via Università 100, Portici, 80055 Naples, Italy
Bulgari et al. 2019; Pellegrini et al. 2020). Recently, the European Parliament defined plant biostimulant as 'a product stimulating plant nutrition processes independently of the product's nutrient content with the sole aim of improving one or more of the following characteristics of the plant and its rhizosphere: nutrient use efficiency, tolerance to abiotic stress, quality traits and availability of confined nutrients in soil or rhizosphere' (European Union. 2019). Biostimulants are composed mainly by protein hydrolysates and other N-containing compounds, seaweed extracts, chitosan, humic, and fulvic acids, plant growth-promoting bacteria, and fungi (Yakhin et al. 2017). Microorganisms can enhance plant growth directly by phosphate solubilization, atmospheric nitrogen fixation, iron chelation, and production of secondary metabolites or indirectly by protecting plant from pathogens deleterious effects (Hardoim et al. 2015). To date, few genera are formulating for plant growth promotion or pest and pathogens control. Bacillus is a species-rich genus of Gram-positive rod-shape bacteria inhabiting different environments such as soil, water, and plants. Several strains of the species Bacillus amyloliquefaciens, B. subtilis, B. pasteurii, B. cereus, B. pumilus, B. mycoides, and B. sphaericus 
elicit significant reduction in the incidence or severity of various diseases in different hosts (Ruiu 2018). These results have been reported against fungal and bacterial pathogens, systemic viruses and root-knot nematodes (Choudhary and Johri 2009). Bacillus strains are characterized by heat- and desiccation-resistant spores, which can be easily formulated as stable dry powder, granules or liquid. Bacillus thuringiensis is present in almost $90 \%$ of biopesticides market in USA and in EU (Arthurs and Dara 2019). In Italy, Bacillus-based biostimulants represent the $42 \%$ of the market products. Bacteria belonging to this genus have an impact on human activities, ranging from human health care to agriculture. The most in-depth studied species among this group are the medically relevant $B$. anthracis, the causal agent of anthrax and $B$. cereus known to cause food-borne intoxication (Liu 2011). Little is known about the other species of the genus that are generally considered as contaminant when found in clinical cultures and their potential pathogenicity has been scarcely investigated (Celandroni et al. 2016). However, some reports indicate that these organisms can cause nosocomial infections or severe illness both in immunocompromised and immunocompetent humans, even if rarely (Idelevich et al. 2013; Abrishami et al. 2015).

Thus, the potential human pathogenicity of the Bacillus species, despite these bacteria are commonly considered soil-related organisms, should not be neglected, as they are increasingly isolated from hospitalized patients (Celandroni et al. 2016). In bacteria, the pathogenic potential is related to the presence of several virulence factors. Notably, in B. cereus, these include the secretion of virulence proteins several hemolysins, phospholipases, trimeric toxins (hemolysin BL, HBL; non-hemolytic enterotoxin, $\mathrm{NHE}$ ), cytotoxin $\mathrm{K}$ (CytK) and proteases (Jessberger et al. 2019). In addition, also motility modes, such as swimming and swarming, and biofilm formation could confer pathogenic abilities (Senesi and Ghelardi 2010; Mazzantini et al. 2016). To our knowledge, no comprehensive studies have been carried out to evaluate the potential pathogenicity of microorganisms used as plant growth promoter (PGPR). The massive use of microorganisms without or poor knowledge of their impact on human health could lead to long-lasting consequences. For example, PGPR and biocontrol agent (BCA) can interact with human pathogens harbored by plants, possibly leading to horizontal gene transfer (i.e., resistance to antibiotics) (Van Overbeek et al. 2014; Holden et al. 2015; Bulgari et al. 2019). Moreover, PGPR could evolve new mechanisms for crossing the kingdom border and thus become true or opportunistic pathogens particularly dangerous in immunocompromised individual.

In this study, the bacteria present in commercial biostimulant products were characterized to evaluate their virulence potential by assessing motility and ability to form biofilms, as well as the presence of toxin-encoding genes.

\section{Materials and methods}

\section{Bacteria isolation}

Bacteria strains were isolated from three commercial biostimulants categorized, respectively, as fertilizer with plant action (FP) and fertilizer with soil action (FS) both in the subcategory inoculum with mycorrhizal fungus by the Italian Ministerial Decree 75/2010 (Table 1) by cultivation-dependent methods with and without microbe enrichment. Plant biostimulant was dissolved into Ringer Solution in 1:10 ratio. Then, $100 \mu \mathrm{L}$ for each serial dilution were spread on Luria-Bertani (LB, Merck, Darmstadt, Germany), on Tryptic Soy Agar (TSA, Merck, Darmstadt, Germany) and on Potato Dextrose Agar (PDA, Merck, Darmstadt, Germany) plates and incubated at $30{ }^{\circ} \mathrm{C}$ (LB, TSA) or $24{ }^{\circ} \mathrm{C}$ (PDA) for 5 days.

Two grams of each market biostimulants was dissolved into 200 mL Tryptic Soy Agar (TSB, Merck, Darmstadt, Germany) and shaken at $30^{\circ} \mathrm{C}$ overnight for microbe enrichment. Partial volume $(100 \mu \mathrm{L})$ of homogenates, serially diluted, was incubated on TSA at $30^{\circ} \mathrm{C}$ for 5 days. Bacterial colonies were selected on the basis of phenotypic traits and isolated.
Table 1 Commercial biostimulants' details

\begin{tabular}{|c|c|c|c|c|}
\hline Product & Composition & Concentration & Formulation & Dose \\
\hline Fertilizer with action on plant & $\begin{array}{l}\text { Mycorrhizae } \\
\text { Trichoderma sp. } \\
\text { Rhizosphere bacteria }\end{array}$ & $\begin{array}{l}0.10 \% \\
1 \times 10^{5} \mathrm{UFC} / \mathrm{g} \\
1 \times 10^{7} \mathrm{UFC} / \mathrm{g}\end{array}$ & Microgranules & $15 \mathrm{~kg} / \mathrm{ha}$ \\
\hline Fertilizer with action on soil & $\begin{array}{l}\text { Glomus intraradices } \\
\text { strain CMC- } \\
\text { CROC7 } \\
\text { Rhizosphere bacteria }\end{array}$ & $1 \times 10 \mathrm{UFC} / \mathrm{g}$ & Powder & $1 \mathrm{~kg} / \mathrm{ha}$ \\
\hline Fertilizer with action on soil & $\begin{array}{l}\text { Mycorrhizae } \\
\text { Trichoderma sp. } \\
\text { Rhizosphere bacteria }\end{array}$ & $\begin{array}{l}0.50 \% \\
1.3 \times 10^{7} \mathrm{UFC} / \mathrm{g} \\
1.2 \times 10^{8} \mathrm{UFC} / \mathrm{g}\end{array}$ & Liquid & $15 \mathrm{~mL} / 20 \mathrm{~L}$ water \\
\hline
\end{tabular}




\section{Bacteria identification}

Genomic DNA was extracted from pure culture using "DNeasy Blood \& Tissue Kit" (Qiagen, Hilden, Germany) following manufacturer's instruction. The bacterial $16 \mathrm{~S}$ rRNA gene was amplified by 27F/1492r (Lane 1991; Chelius and Triplett 2001) following PCR conditions previously described (Bulgari et al. 2009); PCR products were sequenced using Microsynth (Microsynth AG, Balgach$\mathrm{CH})$ Sanger Sequencing Service. The obtained electropherograms were manually edited and checked using Geneious Pro R10 (Biomatters Ltd., Auckland, New Zealand). Sequences were compared with those contained into NCBI (National Center for Biotechnology Information) database using BLAST Nucleotide (https://blast.ncbi.nlm. nih.gov/Blast.cgi) selecting the option 'Limit to Sequences from type material' and the taxonomy tentatively assigned with RDP classifier (http://rdp.cme.msu.edu/classifier/ classifier.jsp). To investigate the phylogenetic relationships of the isolated bacteria, 17 orthologous sequences to those amplified in the present study (16S rRNA) were retrieved from GenBank (https://www.ncbi.nlm.nih.gov/genbank/) for the following taxa: Bacillus, Franconibacter, Stenotrophomonas, Neobacillus, Peribacillus and of Thermotoga maritima NR029163 (considered as outgroup). The 16S rRNA sequences retrieved from GenBank plus those obtained in the present study (only one sequence per haplotype was retained) were aligned using MAFFT (Katoh et al. 2005), with E-INS-i iterative refinement methods. The selection of nucleotide evolution model best fitting the sequence alignment and the phylogenetic inference adopting Bayesian and Maximum Likelihood approaches were performed as previously described (Montagna et al. 2016). Briefly, jModelTest 2 (Darriba et al. 2012), with the adoption of the Akaike Information Criteria (Akaike 1973), was used to estimate and evaluate the model of nucleotide evolution; GTR (Lanave et al. 1984) + gamma distribution $(\Gamma)+$ proportion of invariant sites (I) was selected as best model of nucleotide evolution. Bayesian analyses were performed using MrBayes 3.2 (Ronquist et al. 2012) with the following parameters: GTR $+\mathrm{I}+\Gamma$ model of nucleotide evolution, two runs with four chains of $30 \times 10^{\wedge} 6 \mathrm{MCMC}$ generations, thinning every 1,000 generations, and a burnin fraction of 0.20. The ML analyses were performed using PhyML 3.0 (Guindon and Gascuel 2003) implementing GTR $+\mathrm{I}+\Gamma$ model of nucleotide evolution, the best of NNI and SPR tree searching operation and computation of the starting tree with BioNJ. Node support was estimated by an approximate likelihood ratio test approach (aLRT) (Anisimova and Gascuel 2006). All trees were rooted on T. maritima (NR029163).

\section{PCR screening of toxin-encoding genes}

The detection of virulence genes inside bacterial genome was verified by PCR amplification. Primers sequences and PCR conditions used to amplify $s p h, b c e T$, entFM/S, piplc, $c y t K$, nheA, nheB, and nheC encoding sphingomyelinase, enterotoxin T and enterotoxin FM/S, PI-PLC, CytK, and the three components of NHE (Ghelardi et al. 2002), respectively, are reported in Supplementary Table 1.

PCRs were assembled in a final volume of $25 \mu \mathrm{L}$ with $1 \mu \mathrm{L}$ of the template DNA $(10 \mathrm{ng} / \mu \mathrm{L}), 0.4 \mathrm{mM}$ of each primer, $0.2 \mathrm{mM}$ of dNTPs, and 2 units/ $\mu \mathrm{L}$ of Taq polymerase (Promega, Madison, USA) in the supplied buffer. The DNA (10 ng/ $\mu \mathrm{L}$ ) extracted by Bacillus cereus ATCC 11,778 was used such as positive control.

\section{Motility test}

Swimming and swarming motility were evaluated as previously described by Celandroni et al 2016. Briefly, for swimming motility assay, a volume of $1 \mu \mathrm{L}$ of the overnight culture $\left(1 \times 10^{8}\right.$ cells $\left./ \mathrm{mL}\right)$ was seeded onto the center of TrM plates ( $1 \%$ tryptone, $0.5 \% \mathrm{NaCl}, 0.25 \%$ agar), then plates were incubated at $30{ }^{\circ} \mathrm{C}$ and $37{ }^{\circ} \mathrm{C}$ in humidified chamber and the diameters of halos due to bacterial migration measured $24 \mathrm{~h}$ after the inoculation. For swarming motility assay $1 \times 10^{4}$ cells $/ \mathrm{mL}$ were spotted onto $\mathrm{TrA}$ (tryptone $1 \%, \mathrm{NaCl}$ $0.5 \%$, agar $0.7 \%$ ) plates, incubating in humidified chamber at $30^{\circ} \mathrm{C}$ and $37^{\circ} \mathrm{C}$ and evaluated over time $(24 \mathrm{~h}, 48 \mathrm{~h}$ and $96 \mathrm{~h}$ ). Furthermore, the rims of growing colonies and of cells were analyzed by light microscope $24 \mathrm{~h}$ and $48 \mathrm{~h}$ after incubation, respectively.

\section{Light and electron microscopy}

The morphology of the bacterial isolates was characterized by light interference contrast (DIC) microscopy using an Olympus BX50 light microscope equipped with a Retiga 2000R (Qimaging, USA) digital camera. Some isolates were also observed by a transmission electron microscope Jeol $100-\mathrm{SX}$ (Jeol, Japan) by negative staining with $2 \%$ uranyl acetate.

\section{Biofilm formation}

The ability of the bacterial strain to form biofilm was tested as previously described by Celandroni et al. (2016). LB overnight cultures of each bacterial strains were adjusted to an optical density of 0.01 at $610 \mathrm{~nm}\left(\mathrm{OD}_{610}\right)$ and incubated in 96 -well plates at $37{ }^{\circ} \mathrm{C}$ for $8 \mathrm{~h}$ and $50 \mathrm{rpm}$ shaking. The isolates were tested in duplicate. The total growth $\left(\mathrm{OD}_{610}\right)$ in each well was measured; planktonic bacteria were removed, and the wells washed with distilled water and air-dried. 
Biofilms were stained with $200 \mu \mathrm{L}$ of $0.3 \%$ crystal violet for $10 \mathrm{~min}$, washed with distilled water, and air-dried. The crystal violet was solubilized with $200 \mu \mathrm{L}$ of $70 \%$ ethanol and the $\mathrm{OD}_{610}$ was measured.

\section{Results and discussion}

\section{Bacteria isolation and identification}

Bacteria and fungi present in three commercial biostimulants were isolated by cultivation-dependent methods (Table 1). No microorganisms were isolated from the fertilizer with action on soil (FS) formulated in liquid. In detail, no Trichoderma species were cultivated even if they were reported on the label confirming that some biostimulants available in the market are of poor quality due to the absence of microorganisms or to the choice of an inappropriate carrier (Pathania et al. 2020). Moreover, the vitality of microorganisms could be affected by incorrect storage, handling and formulation (Singh and Nautiyal 2012; Pathania et al. 2020).

A total of 18 colonies with different morphology were isolated using LB and TSA. Fifteen isolates derived from Fertilizer with action on plant (FP) and 3 from Fertilizer with action on soil (FS) using enrichment method (Table 1). Five colonies, identified by BLAST and RDP analyses on partial 16S rRNA gene sequences, resulted as belonging to the class of Gammaproteobacteria and assigned to the genus Franconibacter (identity $\geq 97.85 \%$ with Franconibacter species) and Stenotrophomonas (identity $\geq 99.88 \%$ with cogenerics); 13 colonies belong to the phylum of Firmicutes and showed high identity values with members of the genus Bacillus (identity $\geq 99.28 \%$ ), Neobacillus and Peribacillus (identity $\geq 97.68 \%$ and identity $\geq 99.31 \%$, respectively) (Table 2). As expected, Bacillus were the most abundant microorganisms resulting present in the commercial biostimulants, Bacillus is a heterogeneous group of bacteria with a different impact on human life ranking from severe illness, food poisoning, industrial and agriculture applications. Bacillus species are in deep studied biostimulants or biocontrol agents. Accordingly, five and two different Bacillus species were isolated from FP and FS biostimulants, respectively. In detail, Bacillus subtilis group is primarily sold as biocontrol agent to control plant pathogens (Dunlap 2019). Surprisingly, the genus Stenotrophomonas was isolated only from FP. Even if Stenotrophomonas species are isolated from rhizosphere and show antifungal activity (Jiang et al. 2021; Schmidt et al. 2021), Stenotrophomonas sp. strain I6 showed high similarity (identity $\geq 99.88 \%$ ) with Stenotrophomonas maltophilia. This species is increasingly reported as an opportunistic and nosocomial pathogens (Alsuhaibani et al. 2021) and it shows resistance to different antibiotics such as carbapenems and fluoroquinolone (Harmon et al. 2019;
Azimi et al. 2021; Bostanghadiri et al. 2021). Results of BLAST and RDP analyses were confirmed by the Bayesian and ML phylogenetic analyses inferred on the basis of the obtained 16S rRNA gene sequences (Fig. 1). Even if 16S rRNA gene sequence analysis limited the ability to distinguish taxa at the species level (Dunlap 2019; Patel and Gupta 2020), the Bacillus core species (Subtilis and Cereus clade) and the new reclassified Peribacillus (Simplex clade) and Neobacillus (Niacini clade) (Patel and Gupta 2020) were clearly figured out. In detail, strains I13, I15-I17, O1, and O3 clustered within a well-supported clade (Bayesian posterior probabilities, BPP $=1$ and aLRT $=1)$ together with Bacillus subtilis subtilis strain NCB $3610\left(\right.$ MK559753 ${ }^{\mathrm{T}}$ ), Bacillus tequilensis strain KCTC 13,622 (MW009674 ${ }^{\mathrm{T}}$ ) and Bacillus velezensis strain CR-502 (MK745998). Among this species, Bacillus velezensis and Bacillus tequilensis have an important role in agriculture due to their plant growthpromotion activity (Dunlap 2019; Kang et al. 2019; Oleńska et al. 2020), but their presence in commercial biostimulant or biofertilizer is underestimated due to misleading taxonomic attribution (Dunlap 2019).

Strain I1 clustered within a well-supported $(\mathrm{BPP}=1$ and aLRT $=1$ ) clade with Bacillus acidiceler (DQ374637), resulted sister of the previously reported Bacillus clade plus Bacillus paramycoides strain NH24A2 (MT256266 ${ }^{\mathrm{T}}$ ) and Bacillus cereus ATCC11778 (AF290546), the reference strain of Cereus clade. This clade includes human pathogens such as $B$. anthracis, but also B. thuringiensis a wellcharacterized biopesticide. Recently, the enteropathogenic potential of Bacillus thuringiensis isolates from biopesticides was assessed underlining the increasing risk for health consumers (Schwenk et al. 2020). Further studies will be carried out to ascertain the enteropathogenic potential of the strain I1 that grouped with bacterial species of Cereus clade.

The two isolated Neobacillus strains, viz., I2 and I4, clustered with Neobacillus niacini strain (MW243014) and of Neobacillus drentensis (MW243007), respectively. This genus was recently defined and included also $B$. vireti and B. cucumis (Patel and Gupta 2020) as reported in the here presented phylogenetic analyses (Fig. 1) Peribacillus strains (I5, I8-I10) grouped together with Peribacillus simplex (MG645295) and Brevibacillus frigoritolerans strain DSM $8801\left(\right.$ MK424281 ${ }^{\mathrm{T}}$ ), BPP support of 0.93 and aLRT of 0.79 . Peribacillus and Neobacillus species were isolated from different environment such as soil and plant roots (Patel and Gupta 2020) but also from human gut and skin (Celandroni et al. 2016; Patel and Gupta 2020).

\section{Swimming motility}

The effectiveness of microbial-based biostimulants is related to many factors such as their ability to colonize, survive, and proliferate for a considerable time inside and/or on plant 
Table 2 Results of BLAST and RDP analyses of partial 16S rRNA gene of bacterial isolated from commercial

\begin{tabular}{|c|c|c|c|c|c|c|}
\hline Group & Isolate & ENA accession $n$ & Family & RDP classifier assignment & GeneBank closest relative & $\%$ identity \\
\hline & I 3 & FR997860 & Enterobacteriaceae & Franconibacter & $\begin{array}{l}\text { Cronobacter muytjen- } \\
\text { sii ATCC 51,329 } \\
\text { (NR_118088) }\end{array}$ & 95.52 \\
\hline & I 7 & FR997864 & & Franconibacter & $\begin{array}{l}\text { Franconibacter helveti- } \\
\text { cus } \text { strain LMG 23,732 } \\
\text { (NR_104980) }\end{array}$ & 97.90 \\
\hline & $\mathrm{O} 2$ & FR997874 & & Franconibacter & $\begin{array}{l}\text { Enterobacter hormaechei } \\
\text { subsp. xiangfangensis strain } \\
\left.\text { LMG 27,195 (MZ540786 }{ }^{\mathrm{T}}\right)\end{array}$ & 96.01 \\
\hline & I 14 & FR997869 & & Franconibacter & $\begin{array}{l}\text { Enterobacter hormaechei } \\
\text { subsp. xiangfangensis strain } \\
\left.\text { LMG 27,195 (MZ540786 }{ }^{\mathrm{T}}\right)\end{array}$ & 96.08 \\
\hline \multirow[t]{17}{*}{ Gammaproteobacteria } & I 6 & FR997863 & Xanthomonadaceae & Stenotrophomonas & $\begin{array}{l}\text { Stenotrophomonas malt- } \\
\text { ophilia } \text { strain MTCC } 434 \\
\left(\mathrm{MZ} 490578^{\mathrm{T}}\right)\end{array}$ & 98.61 \\
\hline & I 1 & FR997858 & Bacillaceae & Bacillus & $\begin{array}{l}\text { Bacillus paramycoides strain } \\
\text { NH24A2 }\left(\text { MT256266 }{ }^{\mathrm{T}}\right)\end{array}$ & 97.35 \\
\hline & $\mathrm{I} 13$ & FR997868 & & Bacillus & $\begin{array}{l}\text { Bacillus tequilensis } \\
\text { strain KCTC 13,622 } \\
\left(\mathrm{MW} 009674^{\mathrm{T}}\right)\end{array}$ & 99.33 \\
\hline & & & & & $\begin{array}{l}\text { Bacillus subtilis subsp. } \\
\text { subtilis strain NCIB } 3610 \\
\left(\mathrm{MK} 559753^{\mathrm{T}}\right)\end{array}$ & 99.10 \\
\hline & I 15 & FR997870 & & Bacillus & $\begin{array}{l}\text { Bacillus tequilensis } \\
\text { strain KCTC 13,622 } \\
\left(\mathrm{MW} 009674^{\mathrm{T}}\right)\end{array}$ & 99.06 \\
\hline & & & & & $\begin{array}{c}\text { Bacillus velezensis strain } \\
\left.\text { CR-502 (MK745998 }{ }^{\mathrm{T}}\right)\end{array}$ & 99.06 \\
\hline & I 16 & FR997871 & & Bacillus & $\begin{array}{l}\text { Bacillus tequilensis } \\
\text { strain KCTC 13,622 } \\
\left(\mathrm{MW} 009674^{\mathrm{T}}\right)\end{array}$ & 98.91 \\
\hline & & & & & $\begin{array}{c}\text { Bacillus velezensis strain } \\
\text { CR-502 }\left(\mathrm{MK} 745998^{\mathrm{T}}\right)\end{array}$ & 98.91 \\
\hline & I 17 & FR997872 & & Bacillus & $\begin{array}{l}\text { Bacillus tequilensis } \\
\text { strain KCTC 13,622 } \\
\left(\mathrm{MW} 009674^{\mathrm{T}}\right)\end{array}$ & 99.31 \\
\hline & & & & & $\begin{array}{l}\text { Bacillus subtilis subsp. } \\
\text { subtilis strain NCIB } 3610 \\
\left(\mathrm{MK} 559753^{\mathrm{T}}\right)\end{array}$ & 98.77 \\
\hline & O 1 & FR997873 & & Bacillus & $\begin{array}{c}\text { Bacillus velezensis strain } \\
\left.\text { CR-502 (MK745998 }{ }^{\mathrm{T}}\right)\end{array}$ & 99.87 \\
\hline & & & & & $\begin{array}{l}\text { Bacillus tequilensis } \\
\text { strain KCTC 13,622 } \\
\left(\mathrm{MW} 009674^{\mathrm{T}}\right)\end{array}$ & 99.33 \\
\hline & O 3 & FR997875 & & Bacillus & $\begin{array}{c}\text { Bacillus velezensis strain } \\
\left.\text { CR-502 (MK745998 }{ }^{\mathrm{T}}\right)\end{array}$ & 99.27 \\
\hline & & & & & $\begin{array}{l}\text { Bacillus tequilensis } \\
\text { strain KCTC 13,622 } \\
\left(\mathrm{MW009674^{ \textrm {T } }}\right)\end{array}$ & 98.70 \\
\hline & & & & & $\begin{array}{l}\text { Bacillus subtilis subsp. } \\
\text { subtilis strain NCIB } 3610 \\
\left(\mathrm{MK} 559753^{\mathrm{T}}\right)\end{array}$ & 98.70 \\
\hline & I 2 & FR997859 & & Neobacillus & $\begin{array}{l}\text { Bacillus drenten- } \\
\text { sis strain NBRC } \\
\text { 102,427 (NR_114085) }\end{array}$ & 97.50 \\
\hline & & & & & $\begin{array}{l}\text { Bacillus cucumis strain AP-6 } \\
\text { (NR_148626) }\end{array}$ & 97.05 \\
\hline
\end{tabular}


Table 2 (continued)

\begin{tabular}{|c|c|c|c|c|c|}
\hline Group & Isolate & ENA accession $n$ Family & RDP classifier assignment & GeneBank closest relative & $\%$ identity \\
\hline & \multirow[t]{3}{*}{ I 4} & \multirow[t]{3}{*}{ FR997861 } & \multirow[t]{3}{*}{ Neobacillus } & $\begin{array}{l}\text { Bacillus niacini strain NBRC } \\
\text { 15,566 (NR_113777) }\end{array}$ & 99.28 \\
\hline & & & & $\begin{array}{l}\text { Bacillus drenten- } \\
\text { sis strain NBRC } \\
\text { 102,427 (NR_114085) }\end{array}$ & 98.68 \\
\hline & & & & $\begin{array}{l}\text { Bacillus vireti strain R-15447 } \\
\text { (NR_025590) }\end{array}$ & 98.32 \\
\hline & I 5 & FR997862 & Peribacillus & $\begin{array}{l}\text { [Brevibacterium] frigori- } \\
\text { tolerans strain DSM } 8801 \\
\left(\mathrm{MK} 424281^{\mathrm{T}}\right)\end{array}$ & 99.78 \\
\hline & I 8 & FR997865 & Peribacillus & $\begin{array}{l}\text { [Brevibacterium] frigoritol- } \\
\text { erans } \text { strain DSM } 8801(\mathrm{~T}) \\
\left(\mathrm{MK} 424281^{\mathrm{T}}\right)\end{array}$ & 99.47 \\
\hline & I 9 & FR997866 & Peribacillus & $\begin{array}{l}\text { [Brevibacterium] frigoritol- } \\
\text { erans strain DSM } 8801(\mathrm{~T}) \\
\left(\mathrm{MK} 424281^{\mathrm{T}}\right)\end{array}$ & 99.31 \\
\hline Firmicutes & $\mathrm{I} 10$ & FR997867 & Peribacillus & $\begin{array}{l}\text { [Brevibacterium] frigoritol- } \\
\text { erans } \text { strain DSM } 8801(\mathrm{~T}) \\
\left(\mathrm{MK} 424281^{\mathrm{T}}\right)\end{array}$ & 99.51 \\
\hline
\end{tabular}

${ }^{\mathrm{T}}$ Type strain

tissues in the presence of indigenous microflora and, at the same time, directly or indirectly antagonize phytopathogens (Lugtenberg and Kamilova 2009; Pathania et al. 2020). The human and plant pathogens shared with beneficial bacteria the colonization process of the host including adhesion, invasion, and establishment. Bacterial movement strategies are the key point of this process (Vicario et al. 2015). Moreover, motility behavior of the bacterial isolates is considered as a crucial prerequisites for the onset of the diarrheal disease (Ghelardi et al. 2002; Mazzantini et al. 2016). The ability of the bacteria isolates to move as a single cell was evaluated at two different temperatures measuring the halo formed around the colony. Only three isolates molecularly identified as Franconibacter sp. isolate I3, isolate I7, isolate $\mathrm{O} 2$ and Peribacillus sp. isolate $\mathrm{I} 10 \mathrm{did}$ not show a swimming-related behavior. The non-swarming attitude in Bacillus simplex was also reported in other studies (Celandroni et al. 2016; Patel and Gupta 2020). The majority of the isolates, 14 out of 18 , had the higher motility at $37^{\circ} \mathrm{C}$. In detail, Bacillus sp. (isolates I13, I15, I16, I17, O1, and O3), and Franconibacter sp. isolate $\mathrm{I} 14$ reached the plate border in $24 \mathrm{~h}$ at both temperatures. On the other hand, Bacillus sp. isolate $\mathrm{I} 1$ and Franconibacter sp. isolate $\mathrm{O} 2$ had higher motility, respectively, at $30{ }^{\circ} \mathrm{C}$ and $37{ }^{\circ} \mathrm{C}$ (Table 3). All the isolates showed a radial halo at $30{ }^{\circ} \mathrm{C}$ except Bacillus sp. isolate I1 that showed a dendritic halo. The dendritic morphology of the halo was also acquired by Franconibacter sp. isolate I14 and Bacillus sp. isolate I16, O1 and O3 at $37{ }^{\circ} \mathrm{C}$ (data not shown). Thus, it can be concluded that the swimming motility of the bacteria isolated from commercial biostimulants is partially temperature-dependent, but highly genus specific. Moreover, the dendritic motility was reported in human pathogens such as Staphylococcus aureus (Pollitt et al. 2015), Pseudomonas aeruginosa and Bacillus subtilis (Kearns 2010).

\section{Swarming motility and biofilm formation}

The collective cells movement on solid media was evaluated at $30^{\circ} \mathrm{C}$ and $37^{\circ} \mathrm{C}$ at different time points. All the tested isolates showed a swarming behavior after $48 \mathrm{~h}$ at $30^{\circ} \mathrm{C}$, while seven isolates started to swarm after $24 \mathrm{~h}$ at $37^{\circ} \mathrm{C}$ (data not shown). On the other hand, Neobacillus sp. isolate I2, I4, and Franconibacter sp. strain 17 were characterized by lag period of $96 \mathrm{~h}$ of non-motile behavior. Only two isolates of Peribacillus sp. displayed a bull's-eye phenotype at $37^{\circ} \mathrm{C}$.

The isolates were clustered in four different morphotypes on the basis of colony rim (Fig. 2). In the first morphotype, the colony rim cells were long, filamentous swarm ones that maintained close cell-to-cell contact along their long axis while coordinately moving outward from the colony border in groups or rafts of tightly bound cells (Fig. 2). The rim cells of the second and third morphotype shared the

Fig. 1 Bayesian phylogram inferred on 16S rRNA gene sequence obtained by the isolated bacteria plus those retrieved from public repositories (see "Materials and methods"). The values reported on the nodes of the main lineages are the Bayesian posterior probabilities and the aLRT values maximum-likelihood bootstrap percentages (values below 0.7 are not reported). The scale bar indicates the distance in substitutions per site 


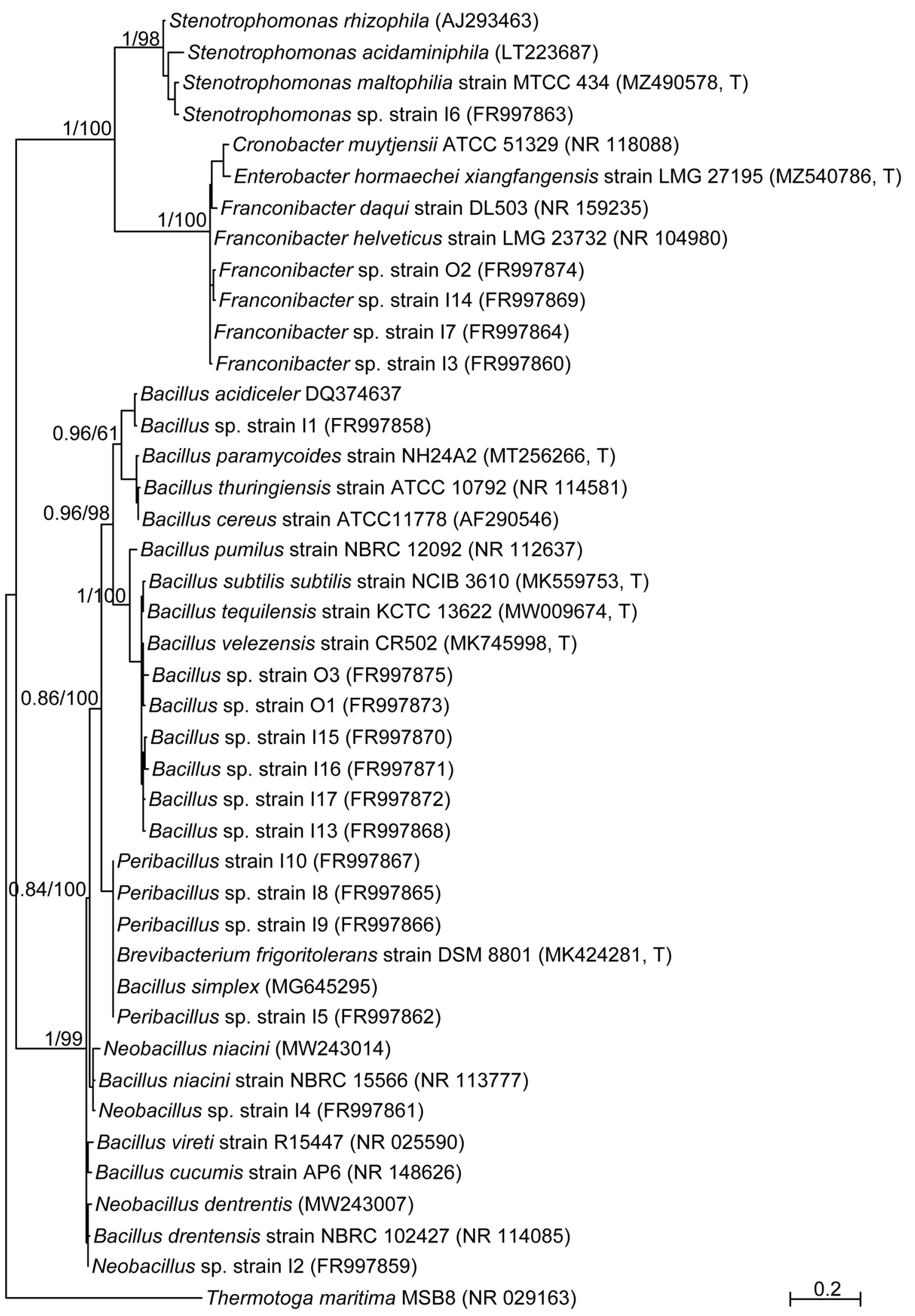


Table 3 Swimming motility of single strains analyzed on TrM plates ( $1 \%$ tryptone, $0.5 \%$ $\mathrm{NaCl}, 0.25 \%$ agar) after $24 \mathrm{~h}$ incubation at $30{ }^{\circ} \mathrm{C}$ and $37 \mathrm{C}$

\begin{tabular}{|c|c|c|c|c|}
\hline Commercial product & Species & Isolates & $\begin{array}{l}\text { Halo at } 30^{\circ} \mathrm{C} \\
(\varnothing \mathrm{mm})\end{array}$ & $\begin{array}{l}\text { Halo at } \\
37^{\circ} \mathrm{C}(\varnothing \\
\mathrm{mm})\end{array}$ \\
\hline \multirow[t]{15}{*}{ Fertilizer with action on plant } & Bacillus sp. & I1 & 15 & 1 \\
\hline & Bacillus sp. & I13 & 50 & 50 \\
\hline & Bacillus sp. & $\mathrm{I} 15$ & 50 & 50 \\
\hline & Bacillus sp. & I16 & 50 & 50 \\
\hline & Bacillus sp. & $\mathrm{I} 17$ & 50 & 50 \\
\hline & Neobacillus sp. & $\mathrm{I} 2$ & 1 & 9 \\
\hline & Neobacillus sp. & I4 & 1 & 7 \\
\hline & Peribacillus sp & I5 & 2 & 6 \\
\hline & Peribacillus sp. & I8 & n.d & 11 \\
\hline & Peribacillus sp. & I9 & 5 & 1 \\
\hline & Peribacillus sp. & $\mathrm{I} 10$ & 1 & 2 \\
\hline & Stenotrophomonas sp. & I6 & 1 & 7 \\
\hline & Franconibacter sp. & $\mathrm{I} 3$ & 1 & 1 \\
\hline & Franconibacter sp. & $\mathrm{I} 14$ & 50 & 50 \\
\hline & Franconibacter $\mathrm{sp}$ & I7 & 1 & 0 \\
\hline \multirow[t]{3}{*}{ Fertilizer with action on soil } & Bacillus sp. & $\mathrm{O} 1$ & 50 & 50 \\
\hline & Bacillus sp. & $\mathrm{O} 3$ & 50 & 50 \\
\hline & Franconibacter sp. & $\mathrm{O} 2$ & 4 & 50 \\
\hline
\end{tabular}

The data represent growth halo 525 diameters $(\varnothing \mathrm{mm})$

\begin{tabular}{|c|c|c|c|c|}
\hline $\begin{array}{l}\text { Swarming phenotype } \\
\text { patterns }\end{array}$ & 1 & 2 & 3 & 4 \\
\hline $\begin{array}{l}\text { Representative } \\
\text { isolate }\end{array}$ & $\mathbf{O 3}$ & I10 & I4 & I13 \\
\hline Nonswarming cells & & & & \\
\hline $\begin{array}{l}\text { Colony rim } \\
\text { swarmino cells }\end{array}$ & & & & \\
\hline Profile colony rim & & & & \\
\hline
\end{tabular}

Fig. 2 Morphological swarming cells' traits and swarming phenotype patterns analyzed by light microscopy, $48 \mathrm{~h}$ after incubation. Strains grown on TrA plates ( $1 \%$ tryptone, $0.5 \% \mathrm{NaCl}, 0.7 \%$ agar); white bars $=10 \mu \mathrm{m}$; black bars $=250 \mu \mathrm{m}$ 
elongated swarm cells and the cell migration all around the colony but differed in the cell density (Fig. 2). The fourth morphotype was associated to dendritic colony with a wavy rim composed by swarming cell in closed contact along their long axis (Fig. 2). Different bacteria changes their morphology substantially while transiting from a planktonic to a swarmer cell, as they become more elongated and their number of flagella significantly increase (Jones et al. 2004; Tuson et al. 2013). Electron microscopy showed an elongated morphology of Bacillus sp. isolate $\mathrm{O} 3$ swarmer cell (Fig. 3).

Flagellum-driven motility, such as swimming or swarming, may facilitate the colonization of different niches or the invasion of human host cellular barriers (Partridge and Harshey 2013). As previously reported for B. cereus, B. pumilus, and B. licheniformis (Celandroni et al. 2016), the high frequency of swimming- and swarming-proficient isolates in our collection suggests that these behaviors could contribute both to the capacity of these strains to colonize plant surfaces and/or to potentially establish an infection in humans.

The biofilm-formation assay was performed in LB medium. Bacillus sp. isolate I1, O1, all Neobacillus sp., Peribacillus sp. isolate I5 and Franconibacter sp. isolate I3, $\mathrm{I} 7$, and $\mathrm{O} 2$ produced biofilm in the tested condition (Fig. 4). On the other hand, in agreement with strong swarming behavior Peribacillus sp., Bacillus sp. (isolate I13, I15, I16, I17 and O3) and Franconibacter sp. isolate I14 were not able to form a biofilm community. The ability of the bacteria to form a biofilm is a common strategy to reduce the effects of
Fig. 3 Morphological traits of isolate $\mathrm{O} 3$ observed by TEM after uranyl staining. a Short cells grown on TSA plates. $\mathbf{b}$ Elongated and chained swarm cells on TrA plates $(0.7 \%$ agar). The cells were picked up from the colony rim after $48 \mathrm{~h}$ incubation at $30^{\circ} \mathrm{C}$ a

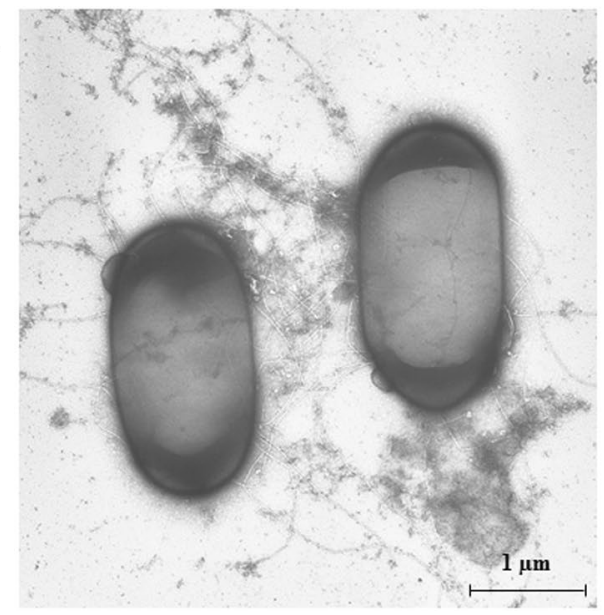

b

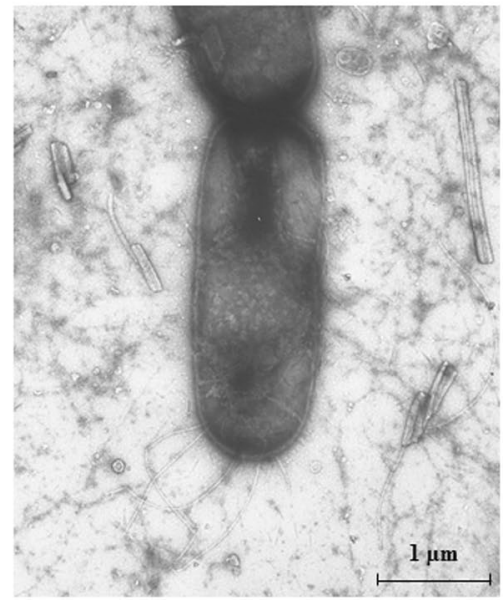

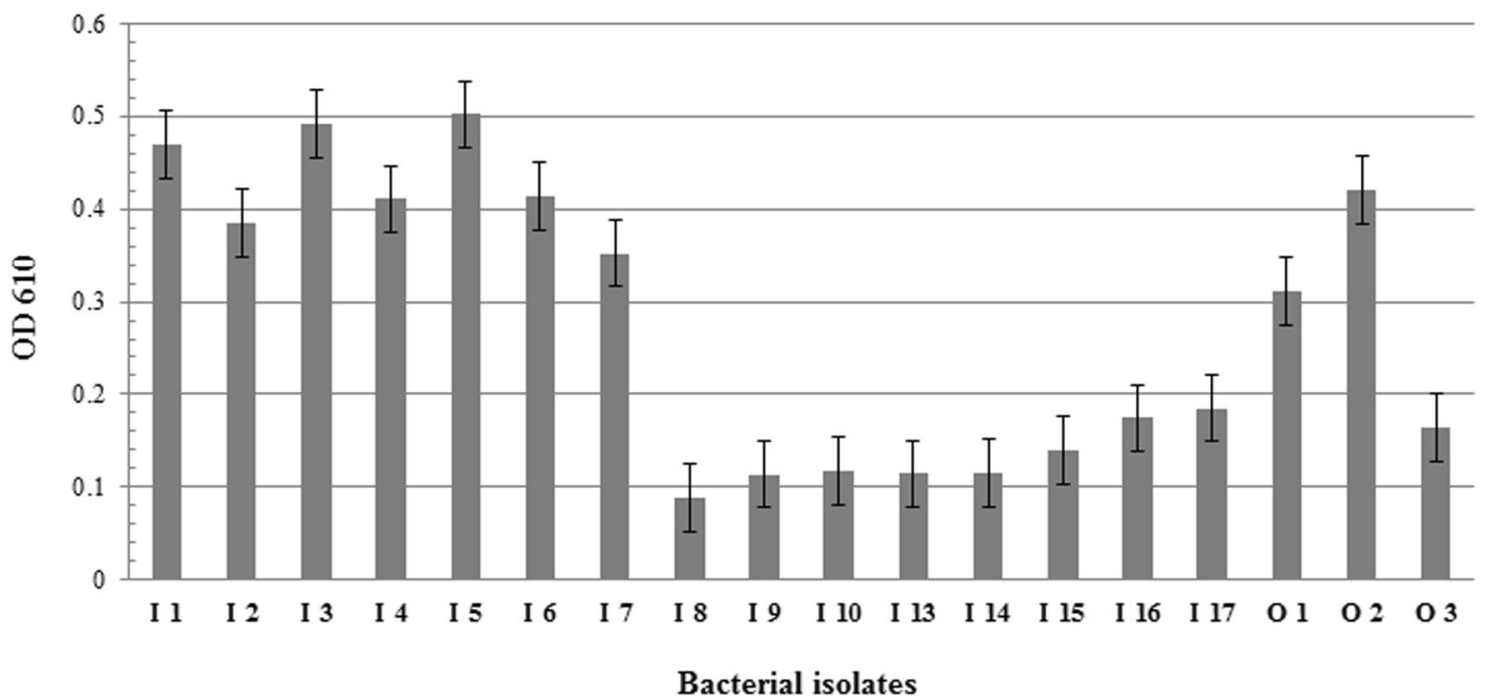

Fig. 4 Biofilm formation quantified by the CV assay. The threshold for biofilm formation (solid line) is equal to the background signal plus two times the standard deviation $(\mathrm{OD}=0.21)$. Values higher than the threshold level were considered positive for biofilm formation 
Table 4 Presence/absence of virulence and toxins/enzymerelated genes in bacteria isolated from two market biostimulants

\begin{tabular}{|c|c|c|c|c|c|c|c|c|c|}
\hline \multirow[t]{2}{*}{ Species } & \multirow[t]{2}{*}{ Isolate } & \multicolumn{4}{|c|}{ Virulence genes } & \multicolumn{4}{|c|}{ Toxins/enzyme } \\
\hline & & $s p h$ & nheA & nheB & nheC & bceT & entS & entFM & piplc \\
\hline Bacillus sp. & I1 & - & - & - & - & - & - & - & - \\
\hline Bacillus sp. & I13 & - & + & - & - & - & - & - & - \\
\hline Bacillus sp. & $\mathrm{I} 15$ & - & - & - & - & - & - & - & - \\
\hline Bacillus sp. & $\mathrm{I} 16$ & - & - & - & - & - & - & - & - \\
\hline Bacillus sp. & $\mathrm{I} 17$ & - & - & - & - & - & - & - & - \\
\hline Bacillus sp. & $\mathrm{O} 1$ & - & - & - & - & - & - & - & - \\
\hline Bacillus sp. & $\mathrm{O} 3$ & - & - & - & - & - & - & - & - \\
\hline Neobacillus sp. & $\mathrm{I} 2$ & - & - & - & - & - & - & - & - \\
\hline Neobacillus sp. & I4 & - & - & - & - & + & - & - & - \\
\hline Peribacillus sp. & I5 & - & - & - & - & + & - & - & - \\
\hline Peribacillus sp. & I8 & - & + & - & + & - & - & - & - \\
\hline Peribacillus sp. & I9 & - & - & - & - & - & - & - & - \\
\hline Peribacillus sp. & $\mathrm{I} 10$ & - & + & - & - & - & - & - & - \\
\hline Franconibacter sp. & I7 & - & - & - & - & - & - & - & - \\
\hline Franconibacter sp. & $\mathrm{I} 3$ & - & + & - & - & + & - & - & - \\
\hline Franconibacter sp. & $\mathrm{O} 2$ & - & - & - & - & - & - & - & - \\
\hline Franconibacter sp. & I14 & - & + & - & + & + & - & - & - \\
\hline Stenotrophomonas sp. & I6 & - & + & - & - & + & - & - & - \\
\hline Bacillus cereus ATCC (control) & & + & + & + & + & + & + & + & + \\
\hline
\end{tabular}

biotic and abiotic stress (Costerton et al. 1995) but also a characteristic trait of PGPR and bacterial human pathogens.

\section{Pathogenic potential}

The presence of virulence genes $s p h$, as well as nheA, nheB and $n h e C$ genes encoding the sphingomyelinase and the three components of NHE, respectively, was evaluated by PCR amplification with available specific primers (Ghelardi et al. 2002). All these genes were detected in Bacillus cereus here used as control (Table 4). None of the isolates had the sphingomyelinase related gene while $n h e A$ was detected in two Peribacillus sp. isolates (I8 and I10), Bacillus sp. isolate I13, Franconibacter sp. isolate I3, I14, and Stenotrophomonas maltophilia isolate I6. Even if Peribacillus sp. isolates I8 and Franconibacter sp. isolate I14 had nheA and $n h e C$ genes, they had not the $n h e B$-related genes as all the other isolates. Sequences of the NHE encoding genes were previously detected in $B$. licheniformis, $B$. simplex, $B$. subtilis, and Paenibacillus spp. (De Bellis et al. 2015). Interestingly, in this work, B. cereus-like toxin genes were found in the genus Cronobacter reported as food-borne pathogens capable of causing intestinal diseases (Jang et al. 2020). Since the full cytotoxic activity of non-hemolytic enterotoxin complex (NHE) required nheA, nheB, and nheC genes (Heilkenbrinker et al. 2013), Peribacillus sp. isolates I8 and Franconibacter sp. isolate I14 probably are not able to cause diarrheal type of food poisoning. As reported by Celandroni and colleagues (Celandroni et al. 2016), gene transfer or evolutionary mechanisms could explain the presence of such sequences in non-B. cereus species.

In addition, enterotoxin FM (EntFM), enterotoxin T (BceT), and enterotoxin S (EntS) were also analyzed out of the B. cereus sensu lato group. As reported in the literature, EntFM and BceT (Bhat et al. 2013; Mohkam et al. 2020; Heo et al. 2021) were not detected in the Bacillus isolates. Interestingly, Bce T was detected in Peribacillus, Neobacillus, and Franconibacter isolates, and in Stenotrophomonas sp.

\section{Conclusion}

Functional tools for evaluating the pathogenic potential are urgently needed to predict hazardous potential of biostimulants.

In this study, cultivation-dependent methods combined to phylogenetic analysis showed the presence of a heterogeneous group of bacterial species in some biostimulants available on the market. Most of them belong to the genus Bacillus and newly defined Neobacillus and Peribacillus. Despite these bacteria are commonly considered soilrelated organisms and PGPR, some of them (isolate I13 and O1) appear sufficiently equipped of virulence properties that could allow them to behave as pathogens/opportunistic pathogens for humans. Unexpectedly, also the genus 
Franconibacter and Stenotrophomonas were isolated from the biostimulants. These genera are reported in close association with plants (Ryan et al. 2009; Zhang et al. 2020), but Stenotrophomonas, particularly, shows a broad activity ranging from PGPR, bioremediation to multidrug-resistance human pathogens (Ryan et al. 2009; Bostanghadiri et al. 2021; Jiang et al. 2021).

In conclusion, the presented approach is useful to easily identify the bacteria present in undeclared rhizosphere bacteria-based formulations. Even more importantly, the combined analysis of motility and ability to form biofilms with the presence of toxin-encoding genes allows to discriminate between PGPR attitude and human pathogen potentiality. This discrimination could be the starting point for the development of a protocol to evaluate the hazardous potential of biostimulant products offering complete information about the safety of the applied strains and formulations to be implemented in routine biostimulant production to safeguard human and environmental health.

Supplementary Information The online version contains supplementary material available at https://doi.org/10.1007/s00203-022-02769-1.

Author contributions DB conceptualized, analyzed, and interpreted the data, and was a major contributor in writing the manuscript. SF performed the experiments. MM supervised the experiments and performed the phylogenetic analyses. EG revised and edited the manuscript. FF conceptualized and supervised the experiments, wroterevised and edited the manuscript. All the authors read and approved the final manuscript.

Funding Not applicable.

Data availability 16 rRNA gene sequences were deposited in the 'European Nucleotide Archive' and they will be permanently available from the ENA browser at http://www.ebi.ac.uk/ena/data/view/FR997858FR997875

\section{Declarations}

Conflict of interest The authors have no conflict of interest to declare.

Ethical approval Not applicable.

Consent to participate Not applicable.

Consent for publication Not applicable.

Open Access This article is licensed under a Creative Commons Attribution 4.0 International License, which permits use, sharing, adaptation, distribution and reproduction in any medium or format, as long as you give appropriate credit to the original author(s) and the source, provide a link to the Creative Commons licence, and indicate if changes were made. The images or other third party material in this article are included in the article's Creative Commons licence, unless indicated otherwise in a credit line to the material. If material is not included in the article's Creative Commons licence and your intended use is not permitted by statutory regulation or exceeds the permitted use, you will need to obtain permission directly from the copyright holder. To view a copy of this licence, visit http://creativecommons.org/licenses/by/4.0/.

\section{References}

Abrishami M, Hashemi B, Abrishami M et al (2015) PCR detection and identification of bacterial contaminants in ocular samples from post-operative endophthalmitis. J Clin Diagnostic Res. https://doi.org/10.7860/JCDR/2015/10291.5733

Akaike H (1973) Information theory and an extension of the maximum likelihood principle. 267-281

Alsuhaibani M, Aljarbou A, Althawadi S et al (2021) Stenotrophomonas maltophilia bacteremia in children: risk factors and mortality rate. Antimicrob Resist Infect Control. https://doi.org/10. 1186/s13756-021-00888-w

Anisimova M, Gascuel O (2006) Approximate likelihood-ratio test for branches: a fast, accurate, and powerful alternative. Syst Biol 55:539-552. https://doi.org/10.1080/10635150600755453

Arthurs S, Dara SK (2019) Microbial biopesticides for invertebrate pests and their markets in the United States. J Invertebr Pathol 165:13-21. https://doi.org/10.1016/j.jip.2018.01.008

Azimi A, Rezaei F, Yaseri M et al (2021) Emergence of fluoroquinolone resistance and possible mechanisms in clinical isolates of Stenotrophomonas maltophilia from Iran. Sci Rep. https:// doi.org/10.1038/s41598-021-88977-z

Bhat AR, Irorere VU, Bartlett T et al (2013) Bacillus subtilis natto: a non-toxic source of poly- $\gamma$-glutamic acid that could be used as a cryoprotectant for probiotic bacteria. AMB Express 3:1-9. https://doi.org/10.1186/2191-0855-3-36

Bostanghadiri N, Ardebili A, Ghalavand Z et al (2021) Antibiotic resistance, biofilm formation, and biofilm-associated genes among Stenotrophomonas maltophilia clinical isolates. BMC Res Notes. https://doi.org/10.1186/s13104-021-05567-y

Bulgari D, Faoro F (2018) Biocontrol could the agroecosystem be the starting point for new human infection? A review. J Agric Food Dev 4:31-35

Bulgari D, Casati P, Brusetti L et al (2009) Endophytic bacterial diversity in grapevine (Vitis vinifera L.) leaves described by $16 \mathrm{~S}$ rRNA gene sequence analysis and length heterogeneity-PCR. J Microbiol 47:393-401. https://doi.org/10.1007/ s12275-009-0082-1

Bulgari D, Montagna M, Gobbi E, Faoro F (2019) Green technology: bacteria-based approach could lead to unsuspected microbeplant-animal interactions. Microorganisms 7:44. https://doi.org/ 10.3390/microorganisms 7020044

Celandroni F, Salvetti S, Gueye SA, Mazzantini D (2016) Identification and pathogenic potential of clinical Bacillus and Paenibacillus Isolates. PLoS ONE. https://doi.org/10.1371/journal. pone. 0152831

Chelius MK, Triplett EW (2001) The diversity of archaea and bacteria in association with the with the roots of Zea mays L. Microb Ecol. https://doi.org/10.1007/s002480000087

Choudhary DK, Johri BN (2009) Interactions of Bacillus spp. and plants-With special reference to induced systemic resistance (ISR). Microbiol Res 164:493-513. https://doi.org/10.1016/j. micres.2008.08.007

Costerton JW, Lewandowski Z, Caldwell DE et al (1995) Microbial biofilms. Annu Rev Microbiol 49:711-745. https://doi.org/10. 1146/annurev.mi.49.100195.003431

Darriba D, Taboada GL, Doallo R, Posada D (2012) jModelTest 2: more models, new heuristics and parallel computing. Nat Methods 9:772. https://doi.org/10.1038/nmeth.2109 
De Bellis P, Minervini F, Di Biase M et al (2015) Toxigenic potential and heat survival of spore-forming bacteria isolated from bread and ingredients. Int J Food Microbiol 197:30-39. https://doi. org/10.1016/j.ijfoodmicro.2014.12.017

Dunlap CA (2019) Taxonomy of registered Bacillus spp. strains used as plant pathogen antagonists. Biol Control 134:82-86. https:// doi.org/10.1016/j.biocontrol.2019.04.011

European Union (2019) Regulation (EU) 2019/1009 of the European Parliament and of the Council of 5 June 2019, laying down rules on the making available on the market of EU fertilising products and amending Regulations (EC) No 1069/2009 and (EC) No 1107/2009 and repealing Regul. Off J Eur Union 2019:1-114

Ghelardi E, Celandroni F, Salvetti S et al (2002) Requirement of flhA for swarming differentiation, flagellin export, and secretion of virulence-associated proteins in Bacillus thuringiensis. J Bacteriol 184:6424-6433. https://doi.org/10.1128/JB.184.23. 6424-6433.2002

Guindon S, Gascuel O (2003) A simple, fast, and accurate algorithm to estimate large phylogenies by maximum likelihood. Syst Biol 52:696-704. https://doi.org/10.1080/10635150390235520

Hardoim PR, van Overbeek LS, Berg G et al (2015) The hidden world within plants: ecological and evolutionary considerations for defining functioning of microbial endophytes. Microbiol Mol Biol Rev 79:293-320. https://doi.org/10.1128/mmbr. 00050-14

Harmon DE, Miranda OA, McCarley A et al (2019) Prevalence and characterization of carbapenem-resistant bacteria in water bodies in the Los Angeles-Southern California area. Microbiologyopen 8:1-13. https://doi.org/10.1002/mbo3.692

Heilkenbrinker U, Dietrich R, Didier A et al (2013) Complex formation between NheB and $\mathrm{NheC}$ is necessary to induce cytotoxic activity by the three-component Bacillus cereus Nhe enterotoxin. PLoS ONE 8:1-11. https://doi.org/10.1371/journal.pone.0063104

Heo S, Kim JH, Kwak MS et al (2021) Functional annotation genome unravels potential probiotic bacillus velezensis strain KMU01 from traditional Korean fermented Kimchi. Foods. https://doi. org/10.3390/foods 10030563

Holden NJ, Jackson RW, Schikora A (2015) Editorial on plants as alternative hosts for human and animal pathogens. Front Microbiol 6:2014-2015. https://doi.org/10.3389/fmicb.2015.00397

Idelevich EA, Pogoda CA, Ballhausen B et al (2013) Pacemaker lead infection and related bacteraemia caused by normal and small colony variant phenotypes of Bacillus licheniformis. J Med Microbiol 62:940-944

Jang H, Gopinath GR, Eshwar A et al (2020) The secretion of toxins and other exoproteins of cronobacter: role in virulence, adaption, and persistence. Microorganisms. https://doi.org/10.3390/ microorganisms 8020229

Jessberger N, Kranzler M, Da Riol C et al (2019) Assessing the toxic potential of enteropathogenic Bacillus cereus. Food Microbiol 84:103276. https://doi.org/10.1016/j.fm.2019.103276

Jiang Y, Yan D, Chen L et al (2021) Diversity of cultured endophyte and rhizosphere bacteria associated with Panax ginseng and screening of their antifungal activity. Fresenius Environ Bull 29:10425-10435

Jones BV, Young R, Mahenthiralingam E, Stickler DJ (2004) Ultrastructure of Proteus mirabilis swarmer cell rafts and role of swarming in catheter-associated urinary tract infection. Infect Immun 72:3941-3950. https://doi.org/10.1128/IAI.72.7.3941-3950.2004

Kang S-M, Khan AL, Waqas M et al (2019) Integrated phytohormone production by the plant growth-promoting rhizobacterium Bacillus tequilensis SSB07 induced thermotolerance in soybean. J Plant Interact 14:416-423. https://doi.org/10.1080/17429145. 2019.1640294
Katoh K, Kuma K, Toh H, Miyata T (2005) MAFFT version 5: improvement in accuracy of multiple sequence alignment. Nucleic Acids Res 33:511-518. https://doi.org/10.1093/nar/gki198

Kearns DB (2010) Swarming. Bee World 8:634-644. https://doi.org/ 10.1038/nrmicro2405

Lanave C, Preparata G, Saccone C, Serio G (1984) A new method for calculating evolutionary substitution rates. J Mol Evol 20:86-93. https://doi.org/10.1007/BF02101990

Lane (1991) 6S/23S rRNA sequencing Nucleic acid techniques in bacterial systematics. In: Stackebrandt MG (ed) Modern microbiological methods. Wiley, pp 133-175

Liu H (2011) Edited by

Lugtenberg B, Kamilova F (2009) Plant-growth-promoting rhizobacteria. Annu Rev Microbiol 63:541-556. https://doi.org/10.1146/ annurev.micro.62.081307.162918

Mazzantini D, Celandroni F, Salvetti S et al (2016) FlhF is required for swarming motility and full pathogenicity of Bacillus cereus. Front Microbiol 7:1-9. https://doi.org/10.3389/fmicb.2016.01644

Mohkam M, Nezafat N, Berenjian A et al (2020) Multifaceted toxin profile of Bacillus probiotic in newly isolated Bacillus spp. from soil rhizosphere. Biologia (bratisl) 75:309-315. https://doi.org/ 10.2478/s11756-019-00357-1

Montagna M, Kubisz D, Mazur MA et al (2016) Exploring specieslevel taxonomy in the Cryptocephalus flavipes species complex (Coleoptera: Chrysomelidae). Zool J Linn Soc 179:92-109. https://doi.org/10.1111/zoj.12445

Oleńska E, Małek W, Wójcik M et al (2020) Beneficial features of plant growth-promoting rhizobacteria for improving plant growth and health in challenging conditions: a methodical review. Sci Total Environ 743:140682

Partridge JD, Harshey RM (2013) Swarming: flexible roaming plans. J Bacteriol 195:909-918. https://doi.org/10.1128/JB.02063-12

Patel S, Gupta RS (2020) A phylogenomic and comparative genomic framework for resolving the polyphyly of the genus bacillus: Proposal for six new genera of Bacillus species, Peribacillus gen. nov., Cytobacillus gen. nov., Mesobacillus gen. nov., Neobacillus gen. nov., Metabacillus. Int J Syst Evol Microbiol 70:406-438. https://doi.org/10.1099/ijsem.0.003775

Pathania P, Rajta A, Singh PC, Bhatia R (2020) Role of plant growthpromoting bacteria in sustainable agriculture. Biocatal Agric Biotechnol 30:101842. https://doi.org/10.1016/j.bcab.2020.101842

Pellegrini M, Pagnani G, Bernardi M et al (2020) Cell-free supernatants of plant growth-promoting bacteria: a review of their use as biostimulant and microbial biocontrol agents in sustainable agriculture. Sustainability. https://doi.org/10.3390/su12239917

Pollitt EJG, Crusz SA, Diggle SP (2015) Staphylococcus aureus forms spreading dendrites that have characteristics of active motility. Sci Rep 5:1-12. https://doi.org/10.1038/srep17698

Ronquist F, Teslenko M, van der Mark P et al (2012) MrBayes 3.2: efficient Bayesian phylogenetic inference and model choice across a large model space. Syst Biol 61:539-542. https://doi.org/10. 1093/sysbio/sys029

Ruiu L (2018) Microbial biopesticides in agroecosystems. Agronomy 8:1-12. https://doi.org/10.3390/agronomy8110235

Ryan RP, Monchy S, Cardinale M et al (2009) The versatility and adaptation of bacteria from the genus Stenotrophomonas. Nat Rev Microbiol 7:514-525. https://doi.org/10.1038/nrmicro2163

Schmidt CS, Mrnka L, Lovecká P et al (2021) Bacterial and fungal endophyte communities in healthy and diseased oilseed rape and their potential for biocontrol of Sclerotinia and Phoma disease. Sci Rep. https://doi.org/10.1038/s41598-021-81937-7

Schwenk V, Riegg J, Lacroix M et al (2020) Enteropathogenic potential of bacillus thuringiensis isolates from soil, animals, food and biopesticides. Foods. https://doi.org/10.3390/foods9101484 
Senesi S, Ghelardi E (2010) Production, secretion and biological activity of Bacillus cereus enterotoxins. Toxins (basel) 2:1690-1703. https://doi.org/10.3390/toxins2071690

Singh PC, Nautiyal CS (2012) A novel method to prepare concentrated conidial biomass formulation of Trichoderma harzianum for seed application. J Appl Microbiol 113:1442-1450

Tuson HH, Copeland MF, Carey S et al (2013) Flagellum density regulates Proteus mirabilis swarmer cell motility in viscous environments. J Bacteriol 195:368-377. https://doi.org/10.1128/JB. 01537-12

Van Overbeek LS, Van Doorn J, Wichers JH et al (2014) The arable ecosystem as battleground for emergence of new human pathogens. Front Microbiol 5:1-17. https://doi.org/10.3389/fmicb.2014. 00104
Vicario JC, Dardanelli MS, Giordano W (2015) Swimming and swarming motility properties of peanut-nodulating rhizobia. FEMS Microbiol Lett 362:1-6. https://doi.org/10.1093/femsle/fnu038

Yakhin OI, Lubyanov AA, Yakhin IA, Brown PH (2017) Biostimulants in plant science: a global perspective. Front Plant Sci. https://doi. org/10.3389/fpls.2016.02049

Zhang Q, Geng Z, Li D, Ding Z (2020) Characterization and discrimination of microbial community and co-occurrence patterns in fresh and strong flavor style flue-cured tobacco leaves. Microbiologyopen. https://doi.org/10.1002/mbo3.965

Publisher's Note Springer Nature remains neutral with regard to jurisdictional claims in published maps and institutional affiliations. 